\title{
SOME INTERNAL CHANGES IN DATE PALM TREES AS A RESULT OF INFESTATION WITH RED PALM WEEVIL, Rhynchophorus ferrugineus OLIVE. (CURCULIONDAE: COLEOPTERA)
}

El-Shazly. E.A.*; Sohair H.F.**; Y. M. El-Sebay ${ }^{\star \star}$; M. M. Abd ElAzim $^{\star *}$ and Eman E. H. El- Rehewy**

* Economic Entomology \& Pesticides Dept., Fac. Agric., Cairo univ. ${ }^{\star *}$ Plant Protection Research Institute, Agric. Res. Cent., Giza, Egypt.

\begin{abstract}
Internal changes of temperature, moisture content and $\mathrm{PH}$ values of infested date palm trees with red palm weevil, Rhynchophorus ferrugineus were studied. The results indicated that internal Palm tree temperature at $6 \mathrm{am}$, Palm tree temperature at $12 \mathrm{pm}$ and mean temperatures were increased in infested areas in infested trees during the different months. . Palm tree temperature at 6 am inside infested trees ranged between $12.8^{\circ} \mathrm{C}$ ( in January) and $34.8^{\circ} \mathrm{C}$ (in August). The differences of Palm tree temperature at $6 \mathrm{am}$. between infested and healthy trees ranged between $0.1^{\circ} \mathrm{C}$ in January and $6.1^{\circ} \mathrm{C}$ in April. Palm tree temperature at $12 \mathrm{pm}$ in infested trees ranged from $11.9{ }^{\circ} \mathrm{C}$ in January to $30^{\circ} \mathrm{C}$ in December and $7.8{ }^{\circ} \mathrm{C}$ in October. Mean temp. in infested trees ranged between $12.4^{\circ} \mathrm{C}$ in January and $32.4^{\circ} \mathrm{C}$ in August, while, the differences ranged between $2.2^{\circ} \mathrm{C}$ in January and $6.9^{\circ} \mathrm{C}$ in October.

The moisture contents decreased in infested trees (ranged between $59.5 \%$ in March and $78.3 \%$ in November, while the differences ranged between $0.2 \%$ in May and $9.6 \%$ in March.

$\mathrm{PH}$ values were lower inside infested areas than in healthy trees, where the range in infested trees fluctuated between 4.23 in May and 5.28 in March. The differences in $\mathrm{PH}$ ranged between 0.45 in March and 1.60 in June.

Keywords: Rhynchophorus ferrugineus, red palm weevil, date palm tree, ecology, temperature, moisture content, relative humidity, $\mathrm{pH}$.
\end{abstract}

\section{INTRODUCTION}

Date palms (Phoenix dactylifera L.), family Arecaceae (Palmaceae), are widely cultivated for their fruit crop products, in addition to the important materials such as fiber, fuel and furniture. Date palm is considered the most important fruit crop and an ornamental plant in the Middle East and Arabian lands (FAO, 1984; Moursy and Saker, 1996).

The red palm weevil (RPW) Rhynchophorus ferrugineus Oliver (Coleoptera: Curculionidae) is the most economically important insect pest of date, coconut, oil and ornamental palms throughout South and Southeast Asia (Kalshoven 1950; Solomon1951; Wattanapongsiri, 1966; Saleh,1974; Shantappa et al.,1979 ; Hussein,1998; Yousif \& Al-Bukiri 2003; and ELSebay,2007). This pest invaded the Arabian Gulf region in mid-1980s and recently in Jordon in 1998. In Egypt, it was discovered for the first time in September 1992 at Al. Kassasseen district (Ismailia governorate) and ElSalhia district (El-Sharkia governorate) and now it established as a primary 
pest of date palm in almost all Egyptian governorates . (Saleh 1992, Cox 1993, Abraham et al., 1998; and Hanounik 1998).

RPW Larvae are the most dangerous and harmful stage, where they feed on the internal tissues of the trunk causing exudation of odorous brown liquid secretion at site of attack and making inner tunnels in all directions, but the most run with inner fibers of palm and upward which may reach to sizeable cavities in advanced infestation, causing a lot of damage to tissues leading to the death of infested palm trees (Batt, 2004).

Many physical changes and chemical reactions occurred because of the infestation, such as fermentation of plant sap and resultant fluids from larval feeding which induce internal changes in infested places as temperature, moisture content and $\mathrm{PH}$ values. The present field study focused mainly on the assessment of Palm tree temperature at $6 \mathrm{am}$, Palm tree temperature at $12 \mathrm{pm}$ and mean temperatures, moisture contents and $\mathrm{PH}$ values of infested places in the trunk of infested date palm trees with RPW comparing with the healthy trees.

\section{MATERIALS AND METHODS}

Field experiments were carried out in Zaghloul date palm orchards at Segnel-qatta and El-Mansouria villages, Embaba district, and Giza governorate, from April, 2006 to March, 2007.

Date palm trees of the same age, size and height were chosen for studying the effect of RPW infestation on some internal factors :

1. Effect of RPW infestation on internal Palm tree temperature at 6 am, Palm tree temperature at $12 \mathrm{pm}$ and mean temperatures of date palm.

Ten healthy and ten advanced infested Zaghloul date palm trees were selected and subjected to field examination.

Twenty mercury thermometers $(30 \mathrm{~cm}$ long) were fixed in chosen infested and healthy trees; one / tree. On both types of palm trees the mercury thermometers were located about 1.5 meter above the ground level especially at place of a thick fluid oozed out for the infested ones.

The sensitive terminals of thermometers were fixed inside holes made by an electrical boring device (each hole measured $20 \mathrm{~cm}$ in depth and $0.8 \mathrm{~cm}$ in diameter) inside the trees, then holes were sealed by cork band, also external parts of the thermometers were insulated using cork bands.

All thermometers were examined daily from April, 2006 to March, 2007. Palm tree temperature at 6 am and Palm tree temperature at $12 \mathrm{pm}$ were recorded two times daily, at about $6 \mathrm{o}^{\prime}$ clock in the morning and at about $12 o^{\prime}$ clock in the Midday. Thereafter, the mean temperatures were calculated.

\section{Effect of RPW infestation on moisture content inside infested places} in date palm trees:

To assess the external relative humidity $(\mathrm{RH})$ and the effect of RPW infestation on the moisture content of infested date palm trees comparing with the uninfested ones from April, 2006 to March, 2007, ten healthy and ten RPW infested date palm tissues were obtained. These tissues were weighed 


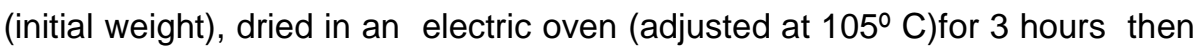
each tissue was weighed at one hour interval until it reached a stable weight (end weight). The percentages of moisture content were estimated according to the following equation:

$$
\text { Percentage of moisture content }=\frac{\text { The initial weight }- \text { The end weight }}{\text { The initial weight }}
$$

\section{Effect of RPW infestation on the PH inside infested places in date palm trees: \\ Trials were conducted in an infested Zaghloul date palm orchard} located at El-Mansouria village, El-Embaba district, Giza governorate, during April 2006 to March 2007.This area was about 5 feddans and the date palm trees aged 5-10 years.

To assess PH changes inside the infested places in the infested date palm trees with RPW, 10 healthy and 10 infested trees were selected for measuring the $\mathrm{PH}$.

Parts from both infested and healthy date palm trees were soaked in a distilled water bath for 5 minutes, then the $\mathrm{PH}$ was measured using the $\mathrm{PH}$ meter.

Monthly inspections were carried out from the first half of April 2006 to the last half of March 2007.

Statistical analyses:

Data of temperature ,moisture content and $\mathrm{pH}$ were analysed statistically by using $\mathrm{T}$-test and regression analysis.

\section{RESULTS AND DISCUSSION}

\section{Internal Palm tree temperature at 6 am, Palm tree temperature at 12} pm and mean temperatures of date palm trees:

Table 1 shows Palm tree temperature at 6 am, Palm tree temperature at $12 \mathrm{pm}$ and mean temperatures inside RPW infested date palm trees in comparison with both the internal temp. of healthy trees and the external temp. (weather temp).

The obtained results revealed that there was an increase in Palm tree temperature at $6 \mathrm{am}$, Palm tree temperature at $12 \mathrm{pm}$ and mean temperatures of infested date palm trees than that of uninfested ones. These results were in agreement with those of Weissling et.al.,(1992) and Abbas (2005) who found certain relationships between weather factors and insect activities.

The highest values of internal Palm tree temperature at 6 am. of infested and healthy palm trees were $34.8^{\circ}$ and $28.8 \mathrm{C}^{\circ}$, respectively, recorded during August, 2006, while the lowest ones were $12.8^{\circ}$ and $12.7^{\circ} \mathrm{C}$ recorded during January, 2007, respectively. The differences between internal Palm tree temperature at 6 am of infested and healthy palm trees ranged between $0.1^{\circ} \mathrm{C}$ during January, 2007 and $6.9^{\circ} \mathrm{C}$ during April, 2006. 
Statistical analysis indicated that there was a highly positive correlation between external and internal Palm tree temperature at 6 am of both infested and healthy trees $(r=0.9784)$, Table (1).

It means that the increase of external temp. was followed by the increase of internal temperatures of infested and uninfested trees.

Internal Palm tree temperature at $12 \mathrm{pm}$. reached the highest value of $30.0^{\circ} \mathrm{C}$ for infested palm trees and $25.2^{\circ} \mathrm{C}$ for healthy ones during August, 2006. The lowest values were $11.9^{\circ} \mathrm{C}$ and $6.8^{\circ} \mathrm{C}$ recorded during January and February, 2007 for infested and healthy trees, respectively. The differences between internal Palm tree temperature at $12 \mathrm{pm}$ of infested and healthy palm trees ranged from $2.1^{\circ} \mathrm{C}$ during December, 2006 to $7.8^{\circ} \mathrm{C}$ during October, 2006.

Table (1): Palm tree temperatures at $12 \mathrm{pm}$, and $6 \mathrm{am}$, minimum and maximum temperatures and mean temperatures inside RPW infested date palm trees, comparing with the uninfested (healthy) ones and weather temperatures during April 2006 to March 2007.

\begin{tabular}{|c|c|c|c|c|c|c|c|c|c|c|c|c|}
\hline \multirow[t]{3}{*}{ Date } & \multirow{2}{*}{\multicolumn{3}{|c|}{$\begin{array}{c}\text { Palm tree } \\
\text { temperature at } \\
12 \mathrm{pm} \\
\text { Internal }\end{array}$}} & \multirow[t]{3}{*}{ Met. } & \multicolumn{4}{|c|}{$\begin{array}{l}\text { Palm tree temperature at } \\
6 \mathrm{am}\end{array}$} & \multicolumn{4}{|c|}{ Mean temperature } \\
\hline & & & & & \multicolumn{3}{|c|}{ Internal } & \multirow[b]{2}{*}{ Met. } & \multicolumn{3}{|c|}{ Internal } & \multirow[b]{2}{*}{ Met. } \\
\hline & \begin{tabular}{|l|} 
Infest. \\
\end{tabular} & Health. & Diff. & & Infest. & Health. & Diff. & & \begin{tabular}{|l|} 
Infest. \\
\end{tabular} & Health. & \begin{tabular}{|l|} 
Diff. \\
\end{tabular} & \\
\hline $\begin{array}{c}\text { Apr. } \\
2006\end{array}$ & 19.4 & 14.8 & 4.5 & 7.7 & 21.9 & 15.0 & 6.9 & 29.4 & 20.6 & 14.9 & 5.7 & 18.6 \\
\hline May & 21.5 & 16.5 & 5.0 & \begin{tabular}{|l|}
16.9 \\
\end{tabular} & 23.9 & 18.5 & 5.4 & \begin{tabular}{|l|}
31.1 \\
\end{tabular} & 22.7 & 17.5 & 5.2 & \begin{tabular}{|l|}
24.0 \\
\end{tabular} \\
\hline June & 25.2 & 20.2 & 5.0 & 21.1 & 28.3 & 22.3 & 5.9 & 34.5 & 26.7 & 21.3 & 5.5 & 27.8 \\
\hline July & 27.7 & 22.8 & 4.9 & 21.8 & 31.1 & 26.2 & 4.9 & 33.9 & 29.4 & 24.5 & 4.9 & 27.9 \\
\hline Aug. & 30.0 & 25.2 & 4.8 & 23.1 & 34.8 & 28.8 & 5.9 & 35.7 & 32.4 & 27.0 & 5.4 & 29.4 \\
\hline Sep. & 29.2 & 23.3 & 5.9 & 21.4 & 31.9 & 27.5 & 4.4 & 34.6 & 30.5 & \begin{tabular}{|l|}
25.4 \\
\end{tabular} & 5.1 & \begin{tabular}{|l|}
28.0 \\
\end{tabular} \\
\hline Oct. & 29.3 & 21.5 & 7.8 & 16.5 & 31.8 & 25.8 & 6.1 & 29.8 & 30.6 & 23.6 & 6.9 & \begin{tabular}{|l|}
23.2 \\
\end{tabular} \\
\hline Nov. & 20.4 & 15.0 & 5.4 & 10.5 & 26.4 & 21.5 & 4.9 & 23.4 & 23.4 & 18.2 & 5.1 & 17.0 \\
\hline Dec. & 13.8 & 11.8 & 2.1 & 7.4 & 19.1 & 12.8 & 6.3 & 20.0 & 16.4 & 12.3 & 4.2 & 13.7 \\
\hline \begin{tabular}{|l|} 
Jan. \\
2007
\end{tabular} & .9 & 7.5 & 4.4 & 8.8 & 12.8 & 12.7 & 0.1 & 18.4 & 12.4 & 10.1 & 2.2 & 13.6 \\
\hline Feb. & 12.2 & 6.8 & 5.3 & 11.0 & 19.5 & 13.9 & 5.6 & 21.3 & 15.8 & 10.4 & 5.5 & \begin{tabular}{|l|}
16.2 \\
\end{tabular} \\
\hline March & 17.4 & 11.6 & 5.8 & 13.1 & 21.5 & 16.9 & 4.7 & 27.9 & 19.4 & 14.2 & 5.2 & 20.5 \\
\hline mean & \multicolumn{2}{|c|}{$25.250^{\mathrm{a}} 20.158^{\mathrm{b}}$} & & & \multicolumn{2}{|c|}{\begin{tabular}{|c|c|c|}
$21.500^{a}$ & $16.41^{b}$ \\
\end{tabular}} & & & $23.35^{a}$ & $18.28^{b}$ & & \\
\hline$r$ & \multicolumn{2}{|c|}{0.5168} & --- & ----- & \multicolumn{2}{|c|}{0.9784} & $\begin{array}{ll}--- \\
\end{array}$ & - & \multicolumn{2}{|c|}{0.896} & -- & ----- \\
\hline$b$ & \multicolumn{2}{|c|}{5.30} & --- & 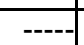 & \multicolumn{2}{|c|}{2.30} & ---- & $-\cdots$ & \multicolumn{2}{|c|}{1.015} & & \\
\hline
\end{tabular}

$r$ between external and internal temperatures

Means in each column followed by different letter are significantly different from each other according to T-test.

Statistical analysis indicated that there was a highly positive correlation between external and internal Palm tree temperature at $12 \mathrm{pm}$ of both infested and healthy trees $(r=0.9784)$.

Concerning the internal mean temp., the highest values, of both 
infested and healthy palm trees, were $32.4^{\circ} \mathrm{C}$ and $27.0^{\circ} \mathrm{C}$, respectively, recorded during August, 2006, while the lowest values were $12.4^{\circ} \mathrm{C}$ and $10.1^{\circ} \mathrm{C}$ recorded during January, 2007 for infested and healthy trees, respectively. The differences between internal mean temperatures of infested and healthy palm trees ranged from $2.2^{\circ} \mathrm{C}$ in January, 2007 to $6.9^{\circ} \mathrm{C}$ in October, 2006.

There was a highly positive correlation between external and internal mean temperatures of both infested and healthy trees $(r=0.896$ and 0.903 , respectively), Table (1). El-Sebay (2003) noted that there was no relationship between seasonal population fluctuctions and weather factors. however krishnakumar and Maheswari (2003) found that the infestation was significantly higher during June which may be correlated with high temperature. Statistical analysis of T-test indicated that there was a significant difference between the means of palm tree temperature at $12 \mathrm{pm}$ of infested and healthy palm trees (25.25 and 20.15 ) Also, significant differences were recorded between means of palm tree temperature at 6 am of infested and healthy trees (21.50 and 16.41). Results also indicated that there was significant differences between of average mean temperatures infested and healthy ones (23.35 and 18.28 ). Table (1).

\section{Moisture content of date palm trees:}

Table 2 presents the effect of RPW infestation on the moisture content of infested date palm trees in relation to the uninfested ones and external relative humidity $(\mathrm{RH})$ during one year, from April 2006 to March 2007.

Data revealed that moisture content was lower inside RPW infested palm trees than in the healthy ones during the whole year of study. The highest percentages of moisture content were 78.3 in November, 2006 and 79.1 in September, 2006 in infested and healthy trees, respectively, while the lowest values were $59.5 \%$ in March, 2007 and $71.0 \%$ in April, 2006 The differences in moisture content between infested and healthy trees ranged from $0.2 \%$ in May, 2006 to $9.6 \%$ in March, 2007.

The correlation between the palm tree temperature at 6 am and the palm tree temperature at $12 \mathrm{pm}$ recorded R.H. and moisture content of healthy and infested trees was insignificant $(r=0.463$ and 0.4678, respectively), There was no correlation between mean $\mathrm{R} . \mathrm{H}$. and moisture content of healthy trees $(r=0.267)$, but it was slightly significant with infested trees $(r=0.695)$. T-test revealed a significant difference between mean infested and healthy palm trees (71.9 and 75. 7) Table (2).

Aldryhim and Khalil (2003) reported that RPW infestation was highly influenced by humidity. On the other hand, Weissling et.al (1992) found a negative correlation between relative humidity and population activity of Rhynchophorus cruentatus.In this study the increase of humidity inside infested parts of trees probably was due to insect feeding and other excreted materials. 
Table (2): The percentages of moisture content of RPW infested and uninfested date palm trees and percentages of R.H during April 2006 to March 2007

\begin{tabular}{|c|c|c|c|c|c|c|}
\hline \multirow{2}{*}{ Date } & \multicolumn{2}{|c|}{ \%Moisture content } & \multirow[b]{2}{*}{ Difference } & \multicolumn{3}{|c|}{ R.H. } \\
\hline & Infested trees & Uninfested trees & & Max. & Min. & Mean \\
\hline Apr. 2006 & 61.5 & 71.0 & 9.5 & 75.7 & 20.9 & 20.9 \\
\hline May & 74.1 & 74.3 & 0.2 & 75.7 & 18.8 & 18.8 \\
\hline June & 71.6 & 72.6 & 1.0 & 74.8 & 22.3 & 22.3 \\
\hline July & 68.3 & 70.0 & 1.7 & 77.7 & 24 & 24 \\
\hline Aug. & 72.7 & 73.4 & 0.7 & 77 & 24.7 & 24.7 \\
\hline Sep. & 77.0 & 79.1 & 2.1 & 77.5 & 24.9 & 24.9 \\
\hline Oct. & 76.3 & 77.5 & 1.2 & 77.2 & 26.7 & 26.7 \\
\hline Nov. & 78.3 & 79.0 & 0.7 & 77 & 31.1 & 31.1 \\
\hline Dec. & 74.8 & 76.8 & 2.0 & 76.1 & 30.6 & 30.6 \\
\hline Jan. 2007 & 76.4 & 77.0 & 0.6 & 77.4 & 30.2 & 30.2 \\
\hline Feb. & 72.4 & 78.8 & 6.4 & 77.4 & 24.9 & 24.9 \\
\hline March & 59.5 & 78.8 & 9.6 & 76.2 & 25.3 & 25.3 \\
\hline Mean & $71.9^{a}$ & $75.7^{b}$ & & & & \\
\hline$r$ & & 4678 & 0.695 & & 463 & 0.267 \\
\hline $\mathrm{b}$ & & .08 & 1.287 & & 465 & 1.033 \\
\hline
\end{tabular}

$r$ between external and internal temperatures

Means in each column followed by different letter are significantly different from each other according to T-test

\section{3. $\mathrm{pH}$ inside infested places in date palm trees:}

Table (3) shows the $\mathrm{pH}$ values inside healthy and infested palm trees from April, 2006 to March, 2007. Data indicated that $\mathrm{pH}$ values were less inside infested places in the infested trees than inside the healthy ones throughout the experimental period.

The highest values of $\mathrm{pH}$ were 5.28 recorded for infested palm trees during March, 2007 and 5.95 for healthy trees during January, 2007, while the lowest vales were 4.23 and 5.29 recorded during May, 2006 for infested and healthy trees, respectively.

The differences between $\mathrm{pH}$ values of infested and healthy trees ranged from 0.45 in March, 2007 to 1.60 in June, 2006.

There was insignificant correlation $(r)$ between $\mathrm{pH}$ values of infested and healthy trees $(r=0.3565)$. T-test indicated that there was significant differences between infested and healthy palm trees (4.6458 and5.6500). Table (3) EL-Bishry et al (2000) found a negative relation between $\mathrm{pH}$ of infested tissues and healthy ones because of tissue acidity. These results agreed with our data. In general, the infestation of RPW affected the inner contents of palm trees in a negative way. 
Table (3): $\mathrm{pH}$ values of infested and uninfested ( healthy ) palm trees from April, 2006 to March, 2007.

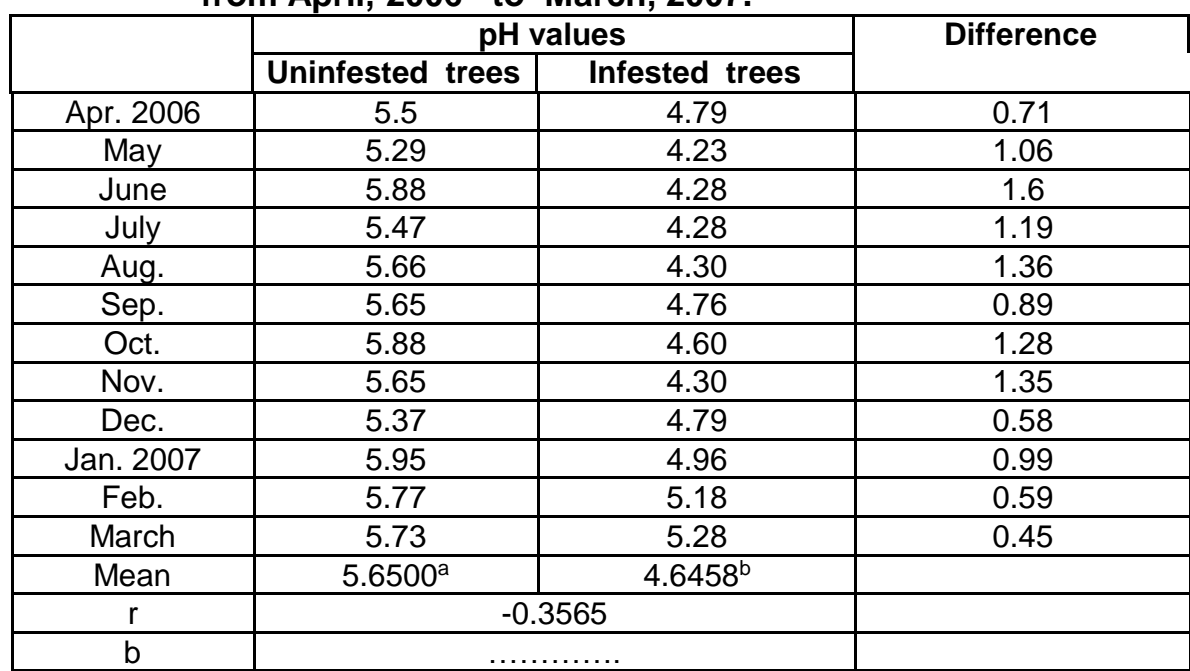

$r$ between external and internal temperatures

Means in each column followed by different letter are significantly different from each other according to T-test.

\section{REFERENCES}

Abbas, A. M. (2005). Integrated management for controlling Red Palm Weevil. Ph. D. Thesis, Fac. Agric., Ain Shams Univ., Egypt, 142 pp.

Abraham, V. A.; M. A. Al-Shuaibi; J. R. Faleiro; R. A. Abouzhairah and P. S. P. V. Vidyasagar (1998). An integrated management approach for red palm weevil, Rhynchopborus ferrugineus Olive., a key pest of date palm in the Middle East. Sultan Qabus University, J. Sci. Res., Agric. Sci. (3): 77-84.

Aldryhim, Y. and A. Khalil (2003). Effect of humidity and soil type on survival and behavior of red palm weevil, Rhynchophorus ferrugineus (Olivier) adult. Agric. and Marine Sci., 8 (2): 87-90.

Batt, A. M. (2004). Field and laboratory observations on some tree borers and their hosts in North Sinai governorate, Egypt. Egypt. J. Agric. Res., 82 (2): 559-572.

Cox, M. I. (1993). Red palm weevil, Rhynchophorus ferrugineus in Egypt. FAO - Plant Protection Bulletin 41 (1): 30-31.

El-Bishry, M. H.; Y. El-Sebay and M. H. Al-Elimi (2000). Impact of the environment in date palm infested with Rhynchophorus ferrugineus on five entomo-pathogenic nematodes (Rhabditida). Int. J. Nematology, 10 (1): 75-80.

El-Sebay, Y. (2003). Ecological studies on the red palm weevil, Rhynchophorus ferrugineus Oliv. (Curculionidae:Coleoptera) in Egypt. Egypt. J. Agric. Res., 81 (2): 523-529. 
El-Sebay, Y. (2007). Studies on the infestation of red palm weevil, Rhynchophorus ferrugineus Oliv. in Egypt. Plant Protec. Res. Ins., Agric. Res. Cent., M. O. A. 2-4 September, 9 pp.

FAO (1984). FAO Production yearbook. Food and Agriculture Organization of the United Nation, Rome.23-25.

Hanounik, S. B. (1998). Steinernematids and heterorhabditids as biological control agents for the red palm weevil, Rhynchophorus ferrugineus Olive. Sultan Qabus University, J. Sci. Res., Agric. Sci., (3): 95-102.

Hussein, A. K. (1998). Biological, ecological and control studies on red palm weevil. M. Sc., Fac. Agric., Zagazig Univ., 285 pp.

Kalshoven, L. G. E. (1950). Pests of crops in Indonesia, P.T. Ichtiar Baru-Van Hoeve, Jakarta. Revised and translated by P.V. Van der Laan 1981, pp 701.

Krishnakumar, R. and P. Maheswari (2003). Seasonal infestation of red palm weevil, Rhynchophorus ferrugineus (Olivier) in Kerala. Insect Environment, 9 (4):174-175.

Moursy, H. and M. Saker (1996). Date palm problems and the need for biotechnology. Abstracts of the $5^{\text {th }}$ Int. Conf. Desert Development, Texas Tech. Univ., USA, August 12- 17, 44- 59.

Saleh, M. R. A. (1992). Red palm weevil (Rhynchophorus ferrugineus Oliver) is the first record for Egypt and indeed the African continent. Int. Instit. Entomol., No. 10634 Africa; collection No. 22563. London, UK.

Saleh, M. R. A. and K. A. Gouhar (1993). Red palm weevil attacking date palm trees in Egypt and limited areas at the present time and how can be eradicated from these areas. A report of Plant Protect. Dept., Fac. Agric., Zagazig Univ., $20 \mathrm{pp}$

Shantappa, P. B.; B. A. Viswanath and V. V. Sulladmath (1979). Red palm weevil, Rhynchophorus ferrugineus from the inland plantations of Karnataka. Current Research, Karnataka, India, 8 (2): 32-40.

Solomon, M. E. (1951). Control of humidity with potassium hydroxide, sulphuric acid, or other solutions. Bull. Ent. Res., 42: 543-554.

Wattanapongsiri, A. (1966). A revision of the genera Rhynchophorus and Dynamis (Coleoptera: Curculionidae). Bangkok, Thailand, Dept. Agric. Sci. Bull. 1, 328 pp.

Weissling, T.U.; R. M. Giblin-Davis; R. H. Scheffrahan and N. M. MarbanMendona (1992). Trap for capturing and retaining Rhynchophorus cruentatus (Coleoptera: Curculionidae) adults using Sabal palmetto as bait. Florida Entomol., 76: 212-221.

Yousif, A. and S. Al-Bukiri (2003). Effect of irrigation on within-grove distribution of red palm weevil, Rhynchophorus ferrugineus Olive. Sultan Qabus University, J. Sci. Res., Agric. Sci., 3 (1): 47-49. 
بعض التغيرات الاخلية فى نخيل البلح نتيجة الإصابة بسوسة النخيل الحمراء

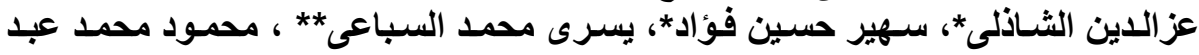

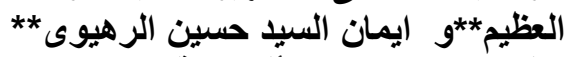

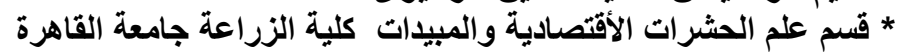

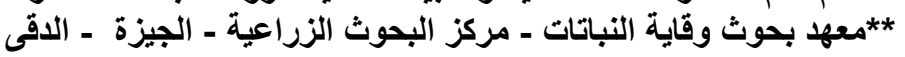

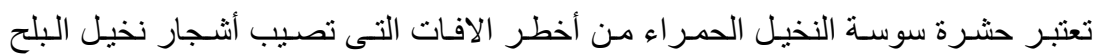

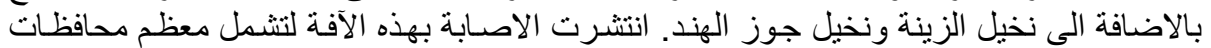

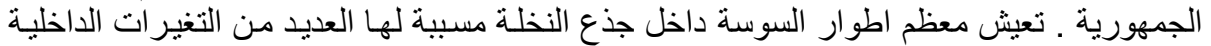

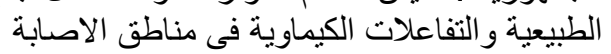
وكانت نتائج هذه الاراسة كالاتئي :

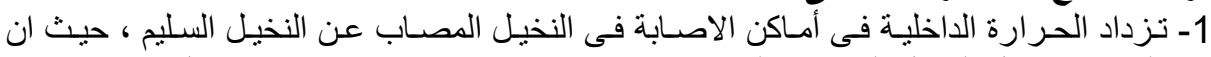

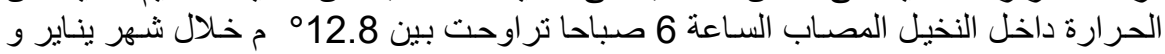
34.8

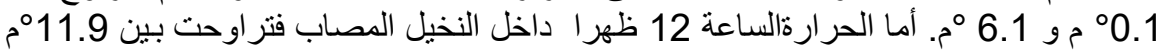

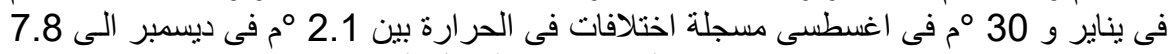

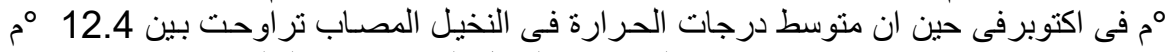

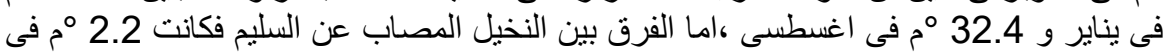

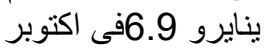

2 - يتناقص المحتوى الرطوبى في في أماكن الاصابة حيث سجل 59.5 \% نوفمبر، بينما تراوح الاختلاف فى النخيل المصاب عن السليم بين 0.2 \% م في مايو و9.5 و في مارس.

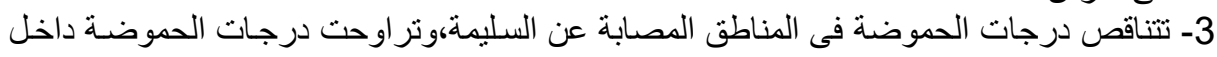

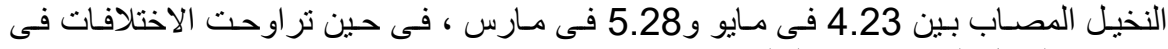
حموضة النخيل المصاب عن السليم بين 0.45 فى مارس و 1.62 في في يونيو ، فين تئرار 